\title{
worldview
}

A JOURNAL OF RELIGION AND INTERNATIONAL AFFAIRS

\section{AIRBORNE ESPIONAGE}

Whatever may be the final effects of the U-2 case on American-Soviet relations (and it is difficult to believe they can be anything but ominous), its results for the prestige of the United States are clearly disastrous. No explanations, no rationalizations, no citing of the Soviet Union's own record of espionage and subversion can rescue our government from the consequences of a major error of judgment.

This error certainly does not lie in the act of espionage itself. The fact that so many Americans were "shocked" when they first learned that their government was engaged in the same spy-business for which they had so long blamed the Russians is a tribute only to the innocence of the American character. Obviously every government-and, in the present world situation, especially the American government-must attempt to discover what its enemies are planning. Any administration which avoided the attempt would betray its obligation to promote the national interest. The moral outrage expressed by $\mathrm{Mr}$. Khrushchev over the proof of American spying is therefore, in itself, a mere gambit. He would think we were fools if we did not send spies to the Soviet Union, just as we would think him stupid if he did not send spies here.

But though espionage itself is necessary in a world divided by fierce power struggles, and though this act is, in a sense, morally "neutral" and "beyond" the realm of international law, it seems clear that it cannot evade the limits of its own logic. Nations cannot agree on nice "rules" for spying; they cannot draft a code for espionage. But it seems that they must admit-and abide by -certain unspoken, unacknowledged canons which are dictated by the logic of international life itself.

Chief among these canons is one, long honored among nations, which says that no government can publicly admit that it has been spying, or, worse still, announce that it intends to spy. Such an admission, or such an announcement, places the nation to be spied upon in an intolerable position. This nation has no choice then (if its world prestige is to stand) except to take some ultimate action against those who have proclaimed their purpose to violate its security.

There would seem to be another rule, inherent in the very nature of espionage, which cannot be violated without disaster for the international community. This canon is analogous to-perhaps identical with-one of the traditional conditions for the launching of a "just" war. It. reads that from this action more good than evil must reasonably be expected, otherwise the undertaking of the action (of war or, by extension, of espionage) is not morally permissible, because it violates reason itself: it is wrong because it is unwise.

In the present world situation airborne espionage seems clearly to violate this canon. Because airborne espionage is an essentially new kind of espionage, and it cannot be justified by classifying it with the traditionally "accepted" forms of spying. A nation can "tolerate" enemy agents within its borders and indeed will expect them to be there, even though it can never admit this and must always be officially outraged when the agents are discovered. But in a world where aircraft are the recognized carriers of sudden, massive death, no nation can tolerate the aircraft of a potential enemy flying over its territory. Still less can it tolerate the announcement that a potential enemy intends to fly aircraft over its territory. A government which did tolerate such things would quickly be no government at all.

In the U-2 case the American government has violated both of these canons. It has, in the first place, used aircraft as an agent of espionage and then, more irresponsibly still, has both acknowledged this use before the nations and suggested that it may continue the practice. Our government has thus given the Soviet government one of its greatest propaganda victories in history. It has also given Mr. Khrushchev one of his few occasions for genuine outraged concern. From all this the major victim must be the United States itself. 